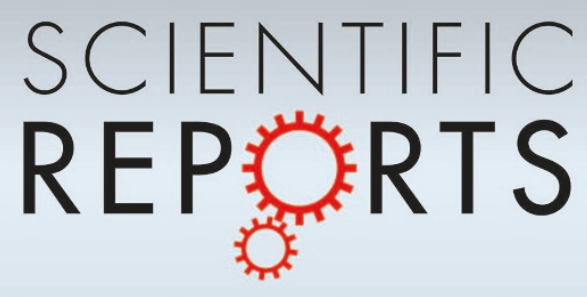

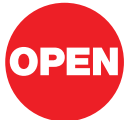

SUBJECT AREAS:

CLIMATE-CHANGE

IMPACTS

PALAEOCLIMATE

OCEAN SCIENCES

PALAEOCEANOGRAPHY

Received

14 February 2013

Accepted

12 April 2013

Published

2 May 2013

Correspondence and requests for materials should be addressed to

S.H. (shetzinger@ geomar.de)

\title{
Coralline algal Barium as indicator for 20th century northwestern North Atlantic surface ocean freshwater variability
}

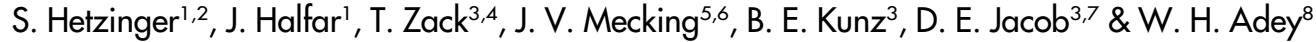

${ }^{1}$ CPS-Department, University of Toronto Mississauga, 3359 Mississauga Rd. N, Mississauga, ON, L5L 1C6, Canada, ${ }^{2}$ GEOMAR Helmholtz-Zentrum für Ozeanforschung Kiel, Wischhofstr. 1-3, 24148 Kiel, Germany, ${ }^{3}$ Earth System Science Research Centre, Department of Geosciences, Becherweg 21, Johannes Gutenberg Universität, D-55099 Mainz, Germany, ${ }^{4}$ Department of Earth Sciences, University of Gothenburg, Box 460, 40530 Gothenburg, Sweden, ${ }^{5}$ GEOMAR Helmholtz-Zentrum für Ozeanforschung Kiel, Düsternbrooker Weg 20, 24105 Kiel, Germany, ${ }^{6}$ Geophysical Institute, University of Bergen, Allegaten 70, 5007 Bergen, Norway, ${ }^{7}$ Earth and Planetary Sciences, Macquarie University, NSW 2109 , Australia, ${ }^{8}$ Department of Botany, Smithsonian Institution, $10^{\text {th }}$ and Constitution Ave, Washington, DC 20560-0166, USA.

During the past decades climate and freshwater dynamics in the northwestern North Atlantic have undergone major changes. Large-scale freshening episodes, related to polar freshwater pulses, have had a strong influence on ocean variability in this climatically important region. However, little is known about variability before 1950, mainly due to the lack of long-term high-resolution marine proxy archives. Here we present the first multidecadal-length records of annually resolved $\mathrm{Ba} / \mathrm{Ca}$ variations from Northwest Atlantic coralline algae. We observe positive relationships between algal $\mathrm{Ba} / \mathrm{Ca}$ ratios from two Newfoundland sites and salinity observations back to 1950 . Both records capture episodical multi-year freshening events during the 20th century. Variability in algal $\mathrm{Ba} / \mathrm{Ca}$ is sensitive to freshwater-induced changes in upper ocean stratification, which affect the transport of cold, Ba-enriched deep waters onto the shelf (highly stratified equals less $\mathrm{Ba} / \mathrm{Ca}$ ). Algal $\mathrm{Ba} / \mathrm{Ca}$ ratios therefore may serve as a new resource for reconstructing past surface ocean freshwater changes.

T

he Northwest Atlantic is a key oceanic region with respect to climate variability. The Nordic, Labrador and Irminger Seas are sites where cold, dense waters are formed. Those water masses are an integral component of what is often termed the Atlantic Meridional Overturning Circulation (AMOC). The AMOC's sensitivity to climatic change remains a subject of intense scientific debate ${ }^{1-3}$ as variability in the strength of the AMOC is thought to have been responsible for significant changes in past climate ${ }^{4}$. The influx of large amounts of freshwater to the northern North Atlantic from the polar regions has been linked to some of the largest changes in AMOC in the past ${ }^{4}$. During recent decades, the Nordic Seas and subpolar basins experienced a significant freshening, with declining salinities indicating that large amounts of freshwater have been added to the northern North Atlantic Ocean since the mid-1960s $\mathrm{s}^{5,6}$. Approximately half of the freshening occurred rapidly during the early 1970s, a period termed the Great Salinity Anomaly (GSA) ${ }^{7}$. The freshening continued at a lesser rate until the late $1990 \mathrm{~s}^{1}$. The GSA has been attributed to several years of anomalously large sea ice export from the Arctic ${ }^{8}$, adding large amounts of fresh water to the northern North Atlantic ${ }^{1}$. These changes in the freshwater system were largely synchronous and correlated with the amplifying North Atlantic Oscillation (NAO) and rising air temperatures during the 1950-2000 period in this region?.

In general, dominant modes of atmospheric and oceanic variability such as the NAO have been linked to environmental change in the Canadian North Atlantic and surrounding regions $\mathrm{s}^{10}$. NAO variability has also affected abundance, biomass, distribution, species assemblages, growth rates, and survival rates for a variety of marine organisms in the northwestern North Atlantic ${ }^{11}$. In fact, NAO forcing has been linked to changes in the transport variability of the Labrador Current ${ }^{12}(\mathrm{LC})$, which has a net cooling effect on both air and coastal water temperatures along the Canadian Atlantic provinces. The LC transports ice and cold freshwater southward along the eastern Labrador and Newfoundland shelf, playing a key role in the heat and freshwater balance of the North Atlantic $^{13}$ (Fig. 1). It is composed of an inshore branch, covering the inner shelf, and an offshore branch centered over the $500 \mathrm{~m}$ isobath at the shelf break, which carries more than $90 \%$ of the total volume transport ${ }^{13}$. Sea ice transport occurs largely on the inner shelf, within the inshore branch of the LC. Seasonal ice melting plays an 


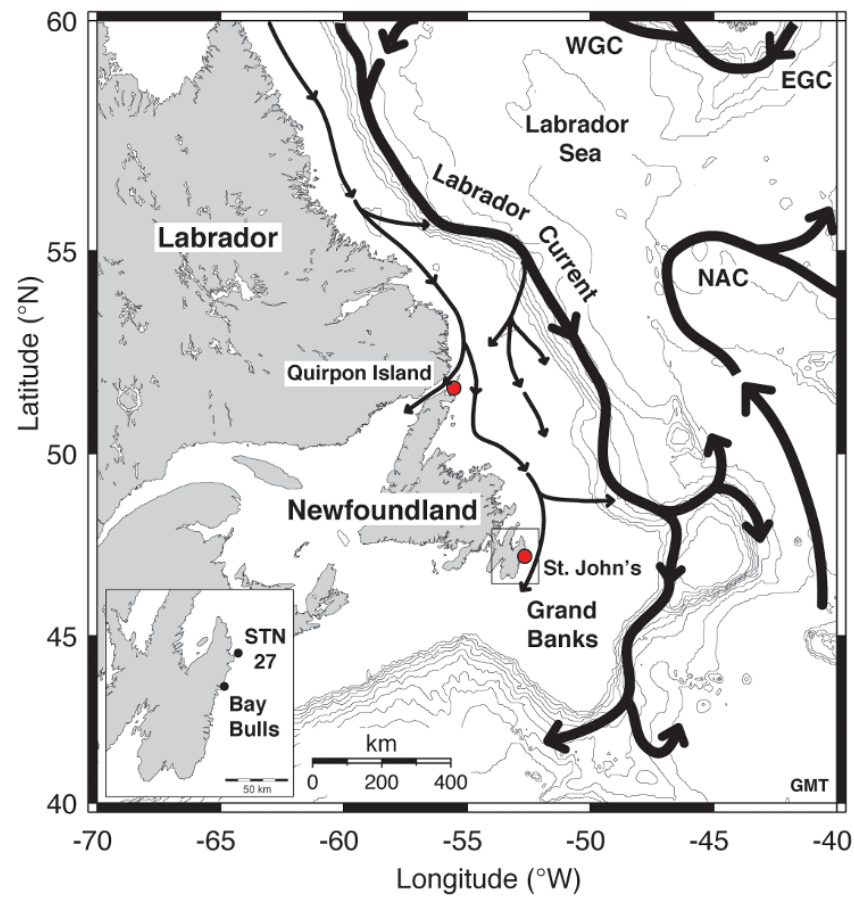

Figure $1 \mid$ Map of northwestern North Atlantic with major ocean currents and study sites. Bold black lines - major ocean currents (EGC East Greenland Current; WGC - West Greenland Current; NAC - North Atlantic Current), black lines - inshore branch of the Labrador Current (LC). Coralline algae sampling sites (red circles): Quirpon Island (QP) and St. John's (SJ). Position of SJ site (collected off Bay Bulls Harbour near St. John's) and oceanographic monitoring Station 27 (STN27) are shown on the insert. Map created using the open source software Generic Mapping Tools (GMT, available at http://gmt.soest.hawaii.edu/).

important role on the Newfoundland and Labrador shelf, generating a large and variable flux of freshwater through the region. Interannual to decadal variability in ocean temperature and salinity is well documented by data collected since the middle of the $20^{\text {th }}$ century at oceanographic Station $27^{14}$. Located only few kilometers offshore St. John's (Fig. 1), this station is ideally positioned to monitor the inshore branch of the LC. On these time scales a significant part of observed temperature and salinity variability on the shelf can be related to large-scale climatological variations, which drive ocean climate throughout the northwestern Atlantic Ocean, e.g. the $\mathrm{NAO}^{15}$. However, due to the lack of long-term observations of oceanographic parameters, spatially and temporally limited monitoring data can only provide snapshots of current oceanographic conditions that could be masked by large intra-annual to inter-decadal variations. Little is known about seasonal- to interannual-scale surface ocean variability before the mid 20th-century. Therefore, understanding long-term variability of the NW-Atlantic current system, as well as the mechanisms responsible for the recently observed changes remain fundamental research questions that require the analysis of long climate time series. Unfortunately, these time series are currently not available.

Skeletons of long-lived marine biota hold the potential to extend instrument-derived observations by several centuries. However, suitable high-resolution marine archives from mid- and high-latitude marine regions have received little attention ${ }^{16}$, despite their importance for fundamental questions of climate research. Recent pilot studies have shown that encrusting coralline algae are well suited as recorders of extratropical paleoclimatic signals due to their (1) common occurrence in mid- to high-latitude oceans, (2) extreme longevity, and (3) ability to produce annual incremental growth patterns in a high $\mathrm{Mg}$-calcite framework that can be targeted for high-resolution geochemical sampling ${ }^{17}$.

Past environmental variability, e.g. changes in sea surface temperature (SST), are archived in the geochemistry of the skeleton of the massive growing genus Clathromorphum, which is widely distributed on rocky substrate along both the subarctic North Atlantic and northern Pacific coastlines ${ }^{18,19}$. Variations in $\mathrm{Mg} / \mathrm{Ca}$ ratios and in the oxygen isotopic composition of skeletons of long-lived coralline algae record ambient seawater temperature over time $e^{20,21}$. A field calibration study conducted in the cold-temperate western North Atlantic $^{17}$ has highlighted the paleoclimatic potential of C. compactum, the subject of this study, and suggested a linkage between geochemical proxies, large-scale SST changes influenced by Labrador Current variability and major climate modes. Other studies from the same region have shown that $\mathrm{Mg} / \mathrm{Ca}$ ratios from this algal species record Newfoundland shelf SST variability and are linked to largescale North Atlantic climate patterns, such as the $\mathrm{NAO}^{22}$.

C. compactum is particularly abundant along the temperate and subarctic eastern Canadian coastline ${ }^{18,23}$. It thrives in water temperatures $<16^{\circ} \mathrm{C}$ and occurs from 1-40 m water depth reaching maximum abundance around $8 \mathrm{~m}^{24}$. Mean annual growth rates of $C$. compactum in Newfoundland range between 250 and $360 \mu \mathrm{m}^{25}$. C. compactum samples that were recently collected along the Labrador coastline yield records that continuously extend back in time for several hundred years (unpublished data).

In a recent study, the trace elemental composition $(\mathrm{Mg} / \mathrm{Ca}, \mathrm{Ba} / \mathrm{Ca}$, $\mathrm{U} / \mathrm{Ca}, \mathrm{Sr} / \mathrm{Ca}$ ) in skeletons of coralline algae from North Atlantic and North Pacific samples (genus Clathromorphum) was investigated using LA-ICP-MS ${ }^{20}$. This has yielded continuous trace elemental records of multidecadal length. Multidecadal algal $\mathrm{Ba} / \mathrm{Ca}$ ratios records from the North Pacific (C. nereostratum) have previously been used as indicators of coastal freshwater runoff ${ }^{26}$. It was shown that $C$. nereostratum $\mathrm{Ba} / \mathrm{Ca}$ ratios can function as a long-term archive for sea surface salinity (SSS) variations and are able to record past episodes of surface ocean freshening.

Here, we provide the first records of monthly-resolved $\mathrm{Ba} / \mathrm{Ca}$ variations of crustose coralline algae extending up to 90 years from two Newfoundland, Canada, sites. Algal Ba/Ca proxy data are compared to instrument-derived surface ocean and climate data. Specifically, we investigate the relationship of algal $\mathrm{Ba} / \mathrm{Ca}$ ratios to changes in surface ocean salinity and freshwater balance over the past decades. Our data suggest that variability in $\mathrm{Ba} / \mathrm{Ca}$ concentrations in the skeleton of Clathromorphum compactum results from changes in the transport of cold, nutrient- and Ba-enriched deep waters (relative to shallow ice-diluted waters) onto the Newfoundland shelf by the inshore branch of the Labrador Current. Both algal $\mathrm{Ba} / \mathrm{Ca}$ records successfully capture episodical multi-year freshening events on the Newfoundland and Labrador shelf during the 20th century and record interannual to decadal-scale variability.

\section{Results}

Reproducibility of elemental ratios. Reproducibility of trace elemental ratios between two individual laser line transects has been verified in a previous study ${ }^{20}$ using sample QP4-4 (study site Quirpon Island, Fig. 1). In addition, mean elemental ratios averaged over individual laser line transects were compared and individual spot analyses were carried out along a profile parallel to one of the laser line transects on the same Newfoundland sample. Results have shown nearly identical values for both approaches, hence demonstrating data reproducibility and chemical homogeneity within the sampled annual bands ${ }^{20}$. A comparison between $\mathrm{Ba} / \mathrm{Ca}$ ratios from two laser line transects measured on different areas of sample SJ28 (study site St. John's, Fig. 1) is shown in Figure 2. Ba/Ca ratios are highly reproducible between transect line 1 and 2 (sample SJ28, $r=0.71$, Fig. 2; $r=0.5$, sample QP4-4, not shown; sign. at $99.9 \%$ level). Elemental ratios from both transects were averaged to 
create a combined single trace elemental data set for each specimen. Sample SJ28 comprises an archive that extends continuously from 1917 to 2008, sample QP4-4 extends from 1938 to 2008.

Oceanographic monitoring data and relationship of algal $\mathrm{Ba} / \mathrm{Ca}$ to temperature. Station 27 is one of the most frequently monitored hydrographic stations in the northwest North Atlantic and records water properties of the inshore branch of the Labrador Current ${ }^{27,28}$ (Fig. 1). The station offers a unique high temporal resolution dataset (monthly resolution, over 50 years of data available), providing one of the longest continuous in situ observational records of surface ocean conditions (e.g. SST, SSS) in the North Atlantic region. Variations in water properties at Station 27 have been shown to be representative of ocean conditions over a broad area of the eastern Newfoundland Shelf down to a water depth of $176 \mathrm{~m}^{28}$. Observations of salinity and temperature at Station 27 show significant interannual to near-decadal fluctuations with highest magnitude of variability in the surface layer (upper $50 \mathrm{~m}$ ), but with matching variability patterns at most depths ${ }^{29}$. In general, salinity data show similar trends as temperature, with fresher-than-normal periods generally corresponding to colder-than-normal conditions on the Newfoundland Shelf up to at least the early 1990s, with the phase of the salinity cycle preceding that of temperature by approx. 5 years in the late 1960 s, but changing to one to two years from the late 1970s to early $1990 \mathrm{~s}^{29}$.

It was recently shown that algal $\mathrm{Mg} / \mathrm{Ca}$ variability in Newfoundland C. compactum samples is highly correlated to local SST observations (Station 27) and gridded SST data $^{22}$, providing a recorder of past changes in Newfoundland shelf SST, as well as for large-scale temperature variability and climate patterns in the northwestern North Atlantic. In contrast, no significant relationships are observed between algal $\mathrm{Ba} / \mathrm{Ca}$ ratios from St. John's (SJ28) and Quirpon Island (QP4-4) and Station 27 SST. This finding is in agreement with previous studies ${ }^{20,26}$, which showed no significant relationships between algal $\mathrm{Ba} / \mathrm{Ca}$ and temperature.

Relationship of algal $\mathrm{Ba} / \mathrm{Ca}$ to salinity and freshwater variability on the Newfoundland shelf. A much higher correlation exists between St. John's algal $\mathrm{Ba} / \mathrm{Ca}$ and instrument-derived surface water salinity at Station 27 (Fig. 3, $\mathrm{r}=0.45$ annual means, 19502006, sign. at $99.9 \%$ level; $r=0.673$-year means). The relationship between Quirpon Island $\mathrm{Ba} / \mathrm{Ca}$ and salinity (Fig. 3, $\mathrm{r}=0.41$ annual means, sign. at $99 \%$ level; $r=0.573$-year means) is similar, but somewhat weaker than between St. John's Ba/Ca and Station 27. This might be related to the fact that the Quirpon site is located at ca. $500 \mathrm{~km}$ distance from Station 27, while the St. John's site is much closer to the station (30 km distance; Fig. 1). Although there is considerable distance between both Newfoundland study sites, $\mathrm{Ba} / \mathrm{Ca}$ records show remarkably similar interannual variability (Figs. 3 and 4). A significant positive relationship is observed between algal $\mathrm{Ba} / \mathrm{Ca}$ from both sites and Station 27 SSS on these timescales, with algal $\mathrm{Ba} / \mathrm{Ca}$ decreasing (increasing) during periods of fresher-than-normal conditions (saltier-than-normal conditions). Hence, the good correspondence between algal Ba/Ca and Station 27 SSS suggests that both algae record large-scale oceanographic variability on the eastern Newfoundland shelf, rather than individual local signals.

A running correlation analysis between annual mean algal $\mathrm{Ba} / \mathrm{Ca}$ from the St. John's site and Station 27 SSS indicates a stable correlation back to 1950 , a decrease in correlation is observed around the year 1980, which coincides with greatest numbers of missing measurements at Station 27 (Fig. 3a). Correlations between Quirpon algal $\mathrm{Ba} / \mathrm{Ca}$ and SSS are similarly high as for the St. John's site, although correlation to SSS is lost after ca. 1995 (Fig. 3b). After 2000 both Ba/ Ca records show opposing trends, with SJ28 Ba/Ca following closely the trend in Station 27 SSS (Fig. 4). In sample QP4-4 a trend to more positive $\mathrm{Ba} / \mathrm{Ca}$ values starts at around the year 2003, 2-3 years later than at the St. John's site, which might be an expression of local influences.

\section{Discussion}

In open ocean settings, $\mathrm{Ba}$ is often enriched in deep waters due to the uptake of $\mathrm{Ba}$ as barite $\left(\mathrm{BaSO}_{4}\right)$, associated with the formation of biological particulate matter ${ }^{30-36}$. Barium concentrations in the surface oceans can also be influenced by coastal input of suspended sediments ${ }^{37}$. Skeletal $\mathrm{Ba} / \mathrm{Ca}$ ratios have proven to be a valuable proxy for seawater $\mathrm{Ba} / \mathrm{Ca}$, providing information on coastal sediment transport, riverine freshwater discharge, salinity, as well as nutrient and alkalinity distributions ${ }^{32,34,38-41}$. Previous studies have shown that $\mathrm{Ba} / \mathrm{Ca}$ ratios in the calcium carbonate skeleton of marine organisms can also be a recorder of historical changes in advection/mixing of cold nutrient-rich deep waters to the surface layer, which is generally depleted in Ba compared to deep ocean waters ${ }^{33}$.

A recent study has shown for the first time that coralline algal $\mathrm{Ba} /$ Ca ratios (Clathromorphum nereostratum) can function as a proxy for surface ocean freshwater changes ${ }^{26}$. At a northern North Pacific site, which is influenced by coastal freshwater runoff, algal $\mathrm{Ba} / \mathrm{Ca}$ ratios were reported to be a measure of variability in surface water Ba-contents. Elevated Ba-contents of the Alaska Coastal Current, related to the seasonal freshwater/runoff peak, go hand in hand with reduced SSS at this site. These freshening events are registered in algal calcite as an increase in $\mathrm{Ba} / \mathrm{Ca}$ ratios, i.e. a negative algal $\mathrm{Ba} / \mathrm{Ca}-\mathrm{SSS}$ relationship.

In contrast, we observe a positive $\mathrm{Ba} / \mathrm{Ca}$ relationship to salinity observations from the Newfoundland shelf (Station 27). Coastal

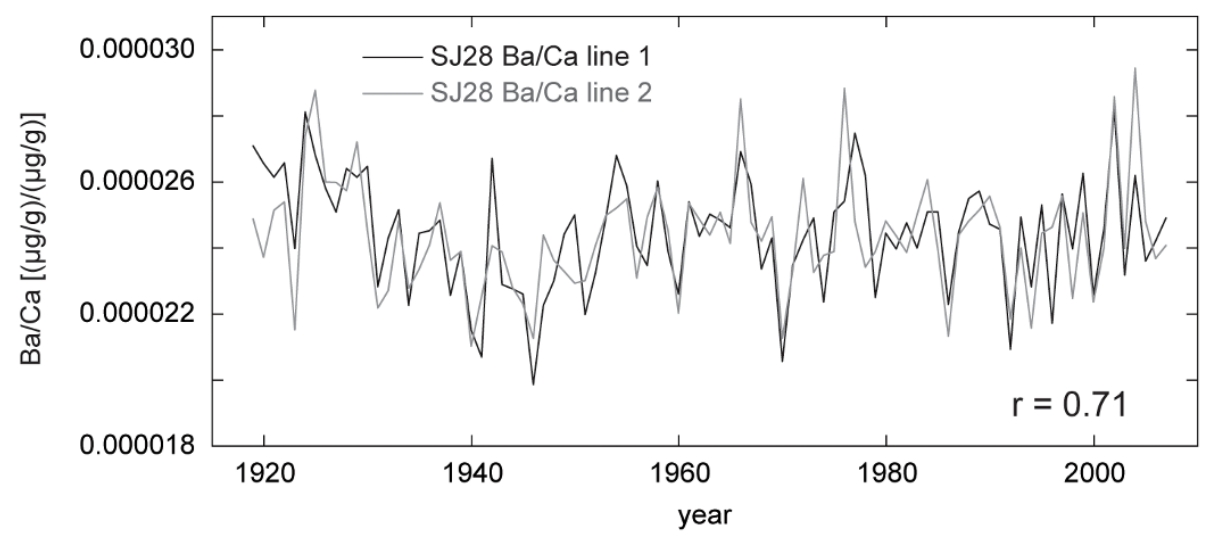

Figure 2 Reproducibility of LA-ICP-MS derived Ba/Ca ratios from sample SJ28. Laser line transects were measured on different parts of the sample (annual resolution, 1919-2007; $\mathrm{r}=0.71$, sign. at 99.9\% level). Black line represents laser line transect 1, grey line transect line 2. 
a St. John's algal Ba/Ca (black) and salinity (red)
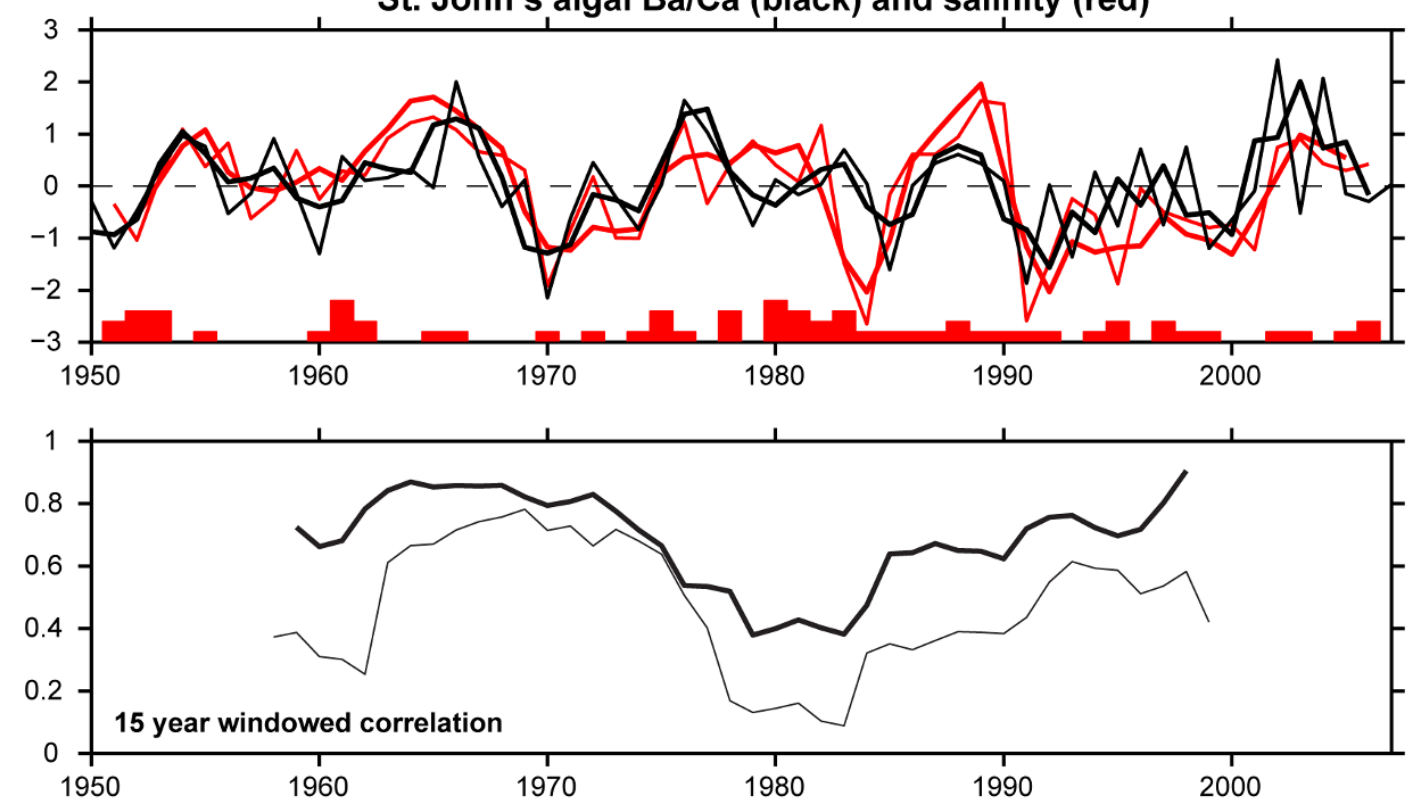

b
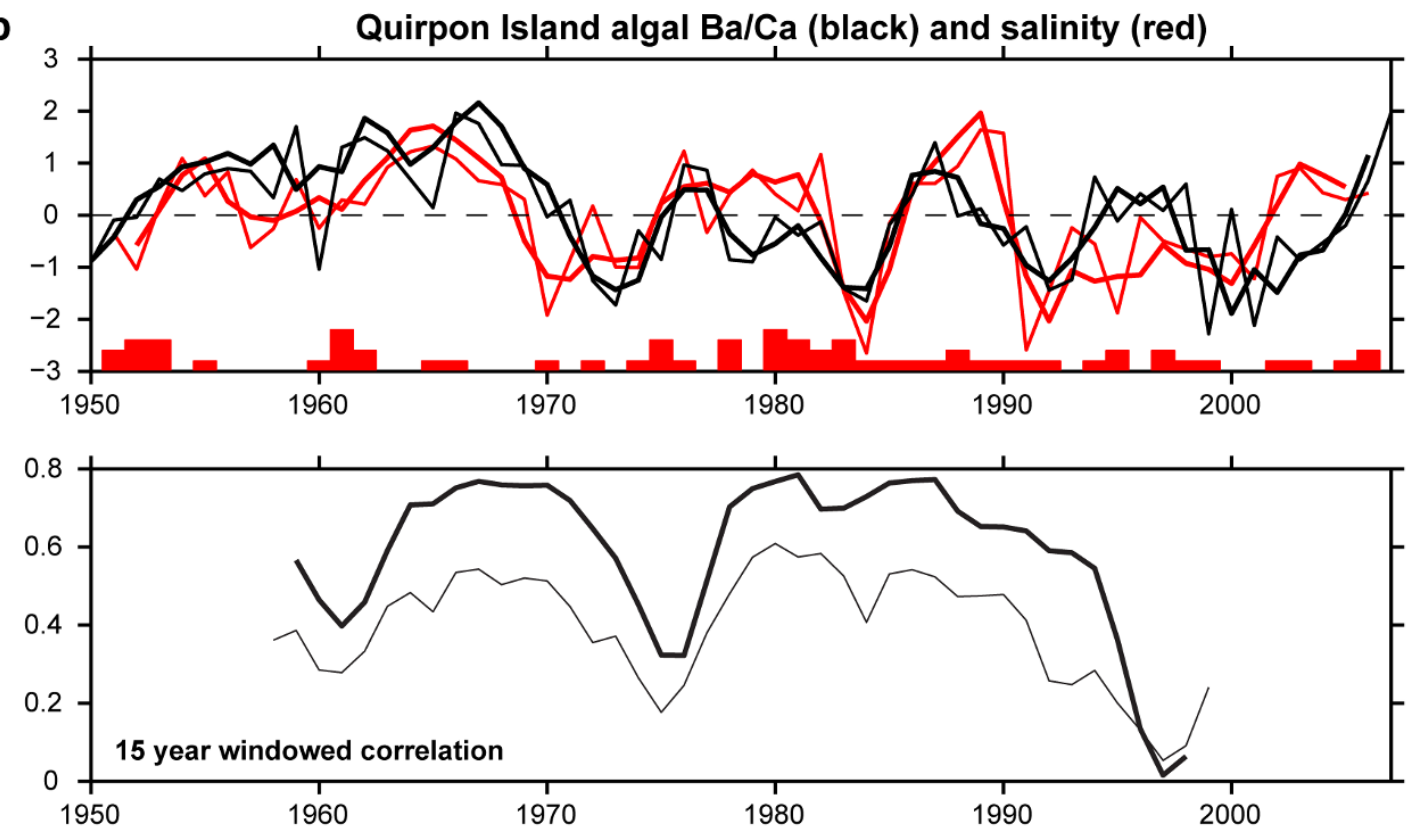

Figure $3 \mid$ Algal Ba/Ca (St. John's and Quirpon Island) and salinity. Sea surface salinity from Station 27 (0 m, red lines) compared to algal Ba/Ca ratios (black lines) from (a) St. John's (SJ28) and (b) Quirpon (QP4-4). Bars in the upper panels display the number of missing months in the Station 27 salinity data (0 to maximum 4 months missing/year of data). Thin lines - annual records; bold lines - three-year moving averages. The salinity and algal Ba/Ca time series are normalized to have mean 0 and standard deviation 1. Lower panels show running correlations between Station 27 SSS and algal Ba/Ca. Correlations are computed using 15 year sliding windows for the three-year running mean data (bold lines) and annual records (thin lines).

runoff plays only a minor role at both Newfoundland sites, instead surface water variability is strongly influenced by seasonal ice-related processes. The Newfoundland and Labrador Shelf is a seasonal ice zone, with sea ice usually present from around midJanuary to March/April. The influence of seasonal sea ice on the oceanographic conditions in this region has been studied by several investigators ${ }^{42-46}$. Freshwater released from spring sea ice melting in the marginal ice zones of the Labrador Sea - including the Newfoundland and Labrador shelves - strengthens upper ocean stratification, and in turn affects salinity and temperature distributions within the mixed layer ${ }^{45,47}$.
Freshwater from sea ice-melt is predominantly responsible for the salinity minimum observed during late summer over much of the Newfoundland shelf $f^{42}$. In general, episodes of increased sea ice melting translate to colder and fresher conditions of the surface layer and characterize years with larger than average seasonal ice extent over both the Labrador and Newfoundland shelves. These episodes are recorded at Station 27 as distinct decreases in SSS and SST (Fig. 4; e.g. early-1970s, early to mid-1980s and early-1990s).

Changes in stratification and vertical mixing processes are known to take place in the surface water masses overlying the Labrador slope and on the shelf ${ }^{48}$. The influence of upwelling has also been 


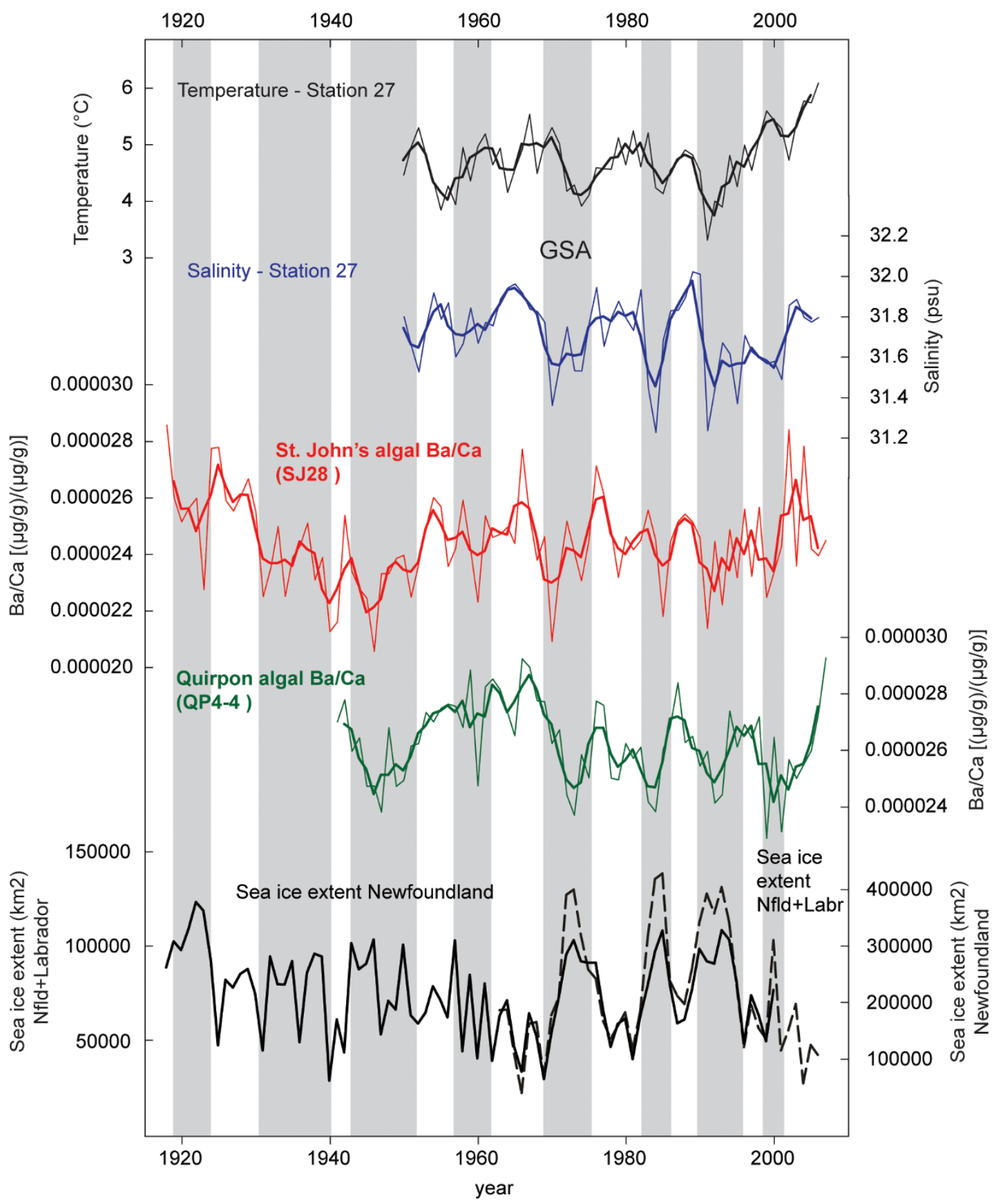

Figure $4 \mid$ Algal Ba/Ca ratios and observational data. Top to bottom: Surface water temperature observed at Station 27 (0 m); Sea surface salinity (0 m) at Station 27 on the Newfoundland Shelf (see Fig. 1 for location); St. John's (sample SJ28) and Quirpon Island (sample QP4-4) algal Ba/Ca ratios. Thin lines - annual records; bold lines - three-year moving averages. Lower panels: Sea ice extent for the eastern Newfoundland shelf (bold line) and combined data for Newfoundland and Labrador shelves (stippled line). Gray bars indicate less saline/fresher episodes corresponding to lower algal Ba/Ca ratios, higher sea ice extent, and often cooler SSTs . GSA marks the Great Salinity Anomaly.

documented in temperature and salinity observations along the sea ice margin off the Newfoundland coast ${ }^{49}$. Recent observations indicate that upwelling of nutrients and downwelling of biomass occurs at the Labrador shelf-break front ${ }^{50}$, the watermass boundary which separates the inshore branch of the Labrador Current on the shelf from the central Labrador Sea and the deep boundary current.

During colder episodes with higher sea ice extent, when input of freshwater from sea ice melting is increased, stratification of the upper ocean is strengthened ${ }^{45,47}$. More stable stratification leads to a reduction of vertical mixing processes, reducing or inhibiting the transport of deeper waters to the surface layer. Thus, less advection of nutrient- and Ba-enriched deep waters to the surface ocean is possible during episodes of increased sea ice melting. During these episodes, when upwelling of deep waters to the shelf is suppressed by increased stratification, and less seawater $\mathrm{Ba}$ (from deep sources) reaches the surface layer, less $\mathrm{Ba}$ is available for uptake into the coralline algal thallus ( skeletal structure) during growth. Hence, such episodes are identifiable in the algal records as decreases in $\mathrm{Ba} / \mathrm{Ca}$ ratios.

Our proxy records show multi-year episodes of decreased $\mathrm{Ba} / \mathrm{Ca}$ ratios corresponding to fresher conditions on the shelf (registered as lower SSS at Station 27, Figs. 3 and 4). This suggests that variability in $\mathrm{Ba} / \mathrm{Ca}$ concentrations in the skeleton of C. compactum at both study sites results mainly from changes in the transport of cold, nutrientand Ba-enriched deep waters (relative to shallow ice-diluted waters) onto the Newfoundland shelf. This mechanism is corroborated by 
the significant negative correlation found between $\mathrm{Ba} / \mathrm{Ca}$ ratios and seasonal winter sea ice extent for the Newfoundland and Labrador shelves (Fig. 4), i.e. decreasing algal $\mathrm{Ba} / \mathrm{Ca}$ during episodes of higher winter sea ice extent, which typically lead to fresher, less saline, conditions and more stable stratification of the mixed layer in the same year.

Further evidence for this mechanism (advection of Ba-enriched deep waters to the surface ocean) comes from the positive relationship found between SSS observations and $\mathrm{Ba} / \mathrm{Ca}$ records (Figs. 3 and 4), which excludes coastal freshwater runoff as a main source of seawater $\mathrm{Ba}$ at these sites. Barium from coastal runoff sources, on the contrary, would manifest as a negative relationship between algal $\mathrm{Ba} / \mathrm{Ca}$ and SSS, e.g. as seen in a previous Clathromorphum study from a northern North Pacific site ${ }^{26}$.

Although both collection sites are $500 \mathrm{~km}$ apart from each other, they are both located in the pathway of the inshore branch of the LC (Fig. 1) and algal $\mathrm{Ba} / \mathrm{Ca}$ records therefore show very similar interannual variability and relationships to Station 27 SSS. Furthermore, both algal records capture large-scale episodic freshening events on the Newfoundland and Labrador shelves (Fig. 4). Salinity minimas on the Newfoundland shelf have been caused by several pulses of freshwater and ice that have been emitted during the past decades from the Arctic ${ }^{1,51}$. These pulses are typically recorded as distinct decreases in SSS at Station 27, and increases in seasonal ice extent on the Newfoundland and Labrador shelves ${ }^{29}$ (Fig. 4). In general, freshwater pulses from the 1960s onwards are stronger in magnitude than those observed during the first half of the 20th century. A freshening trend in Newfoundland shelf surface ocean salinity from the 1960s to the 1990s has been linked to the evolution of the NAO from its most extreme negative state during the 1960s to its most extreme and prolonged positive state in the early $1990 \mathrm{~s}^{52}$. During these three decades lower-than-normal salinities, cold ocean temperatures and heavy ice conditions on the Newfoundland shelf were associated with strong positive NAO index anomalies ${ }^{29,53}$. The longsustained cooling and freshening trends in the upper water column were halted or partly reversed early in the $21^{\text {st }}$ century ${ }^{5}$, when the $\mathrm{NAO}$ index returned to normal/positive values, as recorded by increased SST, SSS and algal Ba/Ca ratios (Fig. 4).

SSS at Station 27 reached low values during the GSA between the late 1960s and mid-1970s, concomitantly with a significant decline in algal $\mathrm{Ba} / \mathrm{Ca}$ at both sites (Fig. 4). Pulses of excess fresh water and ice also have been emitted from the Arctic in the 1980s and 1990s, causing salinity minima on the Newfoundland shelf and subsequent negative anomalies in algal $\mathrm{Ba} / \mathrm{Ca}$ (Fig. 4). In general, freshening of the Subpolar Basins continued from the GSA period into the early $1990 \mathrm{~s}^{1}$. The early-1980s freshening pulse is registered at Station 27 as a negative anomaly in SSS, even more negative than the early-1970s anomaly (GSA), although shorter in duration. At the same time only a weak decrease in Station 27 SST is observed when compared to the stronger negative excursions seen in SST during the early-1970s, and especially the early-1990s freshwater anomalies (Fig. 4). Both algal $\mathrm{Ba} / \mathrm{Ca}$ time series record these freshening pulses as negative excursions of similar duration as in Station 27 SSS. A recent freshening pulse in the year 2000 is registered as a sharp (one-year) positive excursion in ice extent (Fig. 4). Compared to freshwater pulses of the previous decades, the 2000 -event is recorded only as a minor decline in Station 27 SSS, while SST shows no decrease at all. The year 2000 marks the end of a warming trend which has persisted for most of the 1990s. However, both algal records capture this freshening event, displaying a significant decrease in $\mathrm{Ba} / \mathrm{Ca}$ in the same year, although the 2000-event is of much shorter duration than the GSA-event and similar events during the 1980s and 1990s. In summary, algal $\mathrm{Ba} / \mathrm{Ca}$ ratios from both Newfoundland sites capture all multi-year freshening events recorded in Station 27 SSS since 1950, as well as interannual to decadal-scale variability.
Due to the lack of SSS data before 1950, algal Ba/Ca records can only be compared to records of seasonal sea ice extent, which also give information on surface freshwater variability and are available back to 1900. In general, pulses of excess freshwater and ice before the 1960 s seem to be shorter in duration and slightly weaker in magnitude when compared to similar events in the second half of the 20th century. Episodes of significant freshening are observed between around 1930 and 1940, and between the early 1940s and 1950 (Fig. 4). These episodes are recorded as negative excursions in algal records. A strong multi-year increase in ice area extent in the early 1920s, which is comparable in magnitude to the events of the second half of the 20th century, is recorded in algal $\mathrm{Ba} / \mathrm{Ca}$ as a distinct negative excursion. In summary, algal $\mathrm{Ba} / \mathrm{Ca}$ ratios are sensitive to freshwater-induced changes in upper ocean stratification, which affect the transport of $\mathrm{Ba}$-rich deeper waters onto the shelf.

This study presents the first multidecadal-length records of annually resolved $\mathrm{Ba} / \mathrm{Ca}$ variations from Northwest Atlantic coralline algae (C. compactum). Seasonally-resolved algal $\mathrm{Ba} / \mathrm{Ca}$ records were produced using high-resolution sampling by LA-ICP-MS. We investigate proxy records from two study sites on the eastern Newfoundland shelf, which are directly influenced by the inshore branch of the LC. Algal Ba/Ca records show very similar interannual variability indicating that both sites record large-scale variability on the Newfoundland shelf. The availability of an observational record of sea surface variability (SST and SSS), derived from an oceanographic station (Station 27) situated at an ideal location for monitoring changes in the LC inshore branch, allowed us to compare variability in algal proxy records directly to in situ measurements. We found a significant positive relationship between algal $\mathrm{Ba} / \mathrm{Ca}$ records from both sites and Station 27 salinity on interannual time scales, with algal $\mathrm{Ba} / \mathrm{Ca}$ decreasing (increasing) during periods of fresher-than-normal conditions (saltier-than-normal conditions).

Previous studies document the strong influence of ice-derived freshwater on Newfoundland shelf surface water properties. Episodes of higher winter sea ice extents, which go along with increased freshwater input to the surface layer due to higher ice melting, typically lead to a SSS decrease on the Newfoundland and Labrador shelf (documented at Station 27) and more stable stratification of the water column. This, in turn, results in less advection of $\mathrm{Ba}$-rich deep waters to the surface layer. We found that algal $\mathrm{Ba} / \mathrm{Ca}$ ratios are inversely related to historical records of seasonal winter sea ice extent for the Newfoundland and Labrador shelves, i.e. decreasing algal $\mathrm{Ba} / \mathrm{Ca}$ corresponds to episodes of higher winter sea ice extent (positive ice anomalies), during which more stable stratification reduces or hinders the advection of Ba-rich deep waters to the surface. Our data indicate that variability in $\mathrm{Ba} / \mathrm{Ca}$ concentrations in the skeleton of Clathromorphum compactum, which closely follows interannual variability of SSS at Station 27, is sensitive to changes in the transport of cold, nutrient- and Ba-enriched deep waters (relative to shallow ice-diluted waters) onto the Newfoundland shelf. Moreover, episodical multi-year decreases in algal Ba/Ca correspond to individual multi-year freshening events on the Newfoundland and Labrador shelf recorded in Station 27 SSS and to large-scale freshening pulses of the past century documented in sea ice extent observations.

Algal $\mathrm{Ba} / \mathrm{Ca}$ ratios may serve as a new high-resolution proxy for surface ocean salinity and freshwater changes and might provide a new resource for reconstructing past changes in upper ocean stratification in other mid- to high-latitude regions. In light of recently observed freshening trends, affecting interannual- to decadal-scale surface ocean variability in the northern North Atlantic and the Arctic, it is crucial to obtain information on past variability, especially before the period of anthropogenic forcing. Recent rapid mass loss of the Greenland Ice Sheet, which has been linked to ocean warming $^{54}$, has lead to large increases in freshwater fluxes from Greenland into the North Atlantic ${ }^{55}$ and is changing the freshwater 
budget of the region. Thus, longer records from the coralline alga Clathromorphum sp., which can have a multicentury lifespan ${ }^{56}$ and is an important shallow water benthic calcifier in subarctic and arctic regions of the Northern Hemisphere ${ }^{57}$, are expected to provide insights into surface ocean freshwater variability going well back into the past millennium.

\section{Methods}

Collection of crustose coralline algae. Encrusting coralline algae (Clathromorphum compactum) were collected live via SCUBA in the coastal waters of Newfoundland, Canada (Fig. 1, map). Sample QP4-4 was collected off the northern tip of Newfoundland near Quirpon Island (August $2008,51^{\circ} 36.014^{\prime} \mathrm{N}, 55^{\circ} 27.445^{\prime} \mathrm{W}$; Fig. 1; see also Hetzinger et al. ${ }^{20}$, their Fig. 2 for sample image) at $10 \mathrm{~m}$ water depth. Sample SJ28 was collected off Bay Bulls Harbour (near St. John's), southeastern Newfoundland at $10 \mathrm{~m}$ water depth (August $2008,47^{\circ} 18.496^{\prime} \mathrm{N}, 52^{\circ} 47.354^{\prime} \mathrm{W}$; Fig. 1).

Sample preparation and analysis. Polished thick sections of samples were prepared, imaged and analyzed using LA-ICPMS at the Dept. of Geoscience U Mainz following methodology described in detail in Hetzinger et al. ${ }^{20}$. Individual line transects measuring up to $6000 \mu \mathrm{m}$ in length were analyzed with a scan speed of $10 \mu \mathrm{m} / \mathrm{s}$, a spot size of $65 \mu \mathrm{m}$ and $10 \mathrm{~Hz}$ pulse rate. Relative standard deviation (RSD) for repeated analysis of NISTSRM610 (external reproducibility) is ${ }^{24} \mathrm{Mg} /{ }^{43} \mathrm{Ca}=0.67 \%$, ${ }^{137} \mathrm{Ba} /{ }^{43} \mathrm{Ca}=0.47 \%$. Detection limits of reported elements were: $\mathrm{Mg}=0.16 \mathrm{ppm}, \mathrm{Ca}$ $=54.9 \mathrm{ppm}, \mathrm{Ba}=0.13 \mathrm{ppm}$. In order to test and improve the robustness of our data, we analyzed two laser transects on each sample, and averaged the data. Accuracy of $\mathrm{Mg}$ and $\mathrm{Ba}$ contents measured by line scans was previously validated by comparing results from line scans to point measurements that were carried out alongside the laser transects (see Hetzinger et al. ${ }^{20}$, their figure 3B, using sample QP4-4). All data are reported as Element/Ca mass ratios $[(\mu \mathrm{g} / \mathrm{g}) /(\mu \mathrm{g} / \mathrm{g})]$ which can be converted to molar ratios $(\mathrm{mol} / \mathrm{mol})$ by dividing ratios by a conversion divisor $(0.60644$ for $\mathrm{Mg} / \mathrm{Ca}$, 3.42649 for $\mathrm{Ba} / \mathrm{Ca})$.

Chronological development. Chronologies were generated by counting annual growth increments on the mapped and digitized image of the specimens. The yearly "growth" layers are strongly delineated by bands of short, heavily-calcified cells that are formed during the late autumn and winter, when the sporangia are produced. Main vertical growth (=calcification) of the algae occurs during the summer months (June-September) ${ }^{17}$. Overall average annual growth fluctuates between 251-303 micrometer. Age models were established on the basis of the pronounced seasonal cycle in algal $\mathrm{Mg} / \mathrm{Ca}$, with high $\mathrm{Mg}$ values within the skeleton interpreted to correspond to summer periods/growth. Maximum (minimum) $\mathrm{Mg} / \mathrm{Ca}$ values were tied to August (February), which is on average the warmest (coolest) month at the study sites. The algal $\mathrm{Mg} / \mathrm{Ca}$ time series were linearly interpolated between these anchor points using the AnalySeries software ${ }^{58}$ to obtain an equidistant proxy time series with a resolution of 12 samples/year. The developed chronologies were refined and cross checked for possible errors in the age model by comparing annual extreme values in the $\mathrm{Mg} / \mathrm{Ca}$ ratio time series to imaged growth increment patterns for each individual year of algal growth. The $\mathrm{Mg} / \mathrm{Ca}$-based age models were then transferred to algal $\mathrm{Ba} / \mathrm{Ca}$ ratios. On each algal sample two laser transects were measured in parallel orientation in order to reduce intraspecimen variability.

Observational data. Station 27. Instrumental temperature and salinity measurements were obtained from oceanographic Station 27 (0 m water depth; $\left.47.546667^{\circ} \mathrm{N}, 52.586667^{\circ} \mathrm{W}\right)$, which is located $7 \mathrm{~km}$ off St. John's Harbor and in $30 \mathrm{~km}$ distance to the St. John's study site (www.dfo-mpo.gc.ca; see Figure 1). Station 27 provides more than 50 years of in situ measurements of surface ocean parameters in monthly sampling resolution. Station 27 data are available from June 1946 onwards. However, due to data gaps in the years 1946-1949 (more than 4 measurements/year missing) only data from 1950 onwards are used in this study. Missing months were replaced by the average for the respective month calculated from the entire record (1951-2006). Annual averages were calculated based on monthly measurements.

Seasonal sea ice extent. Historical records of ice distribution around Newfoundland were compiled by Brian T. Hill ${ }^{59}$ (http://archive.nrc-cnrc.gc.ca/eng/ibp/iot/research/ ice-databases.html). Seasonal winter sea ice extent for Newfoundland is available from 1810 onwards, sea ice extent for Newfoundland and Labrador combined is available for the time period 1963-2006.

1. Curry, R. \& Mauritzen, C. Dilution of the northern North Atlantic Ocean in recent decades. Science 308, 1772-1774 (2005)

2. Kuhlbrodt, T. et al. An Integrated Assessment of changes in the thermohaline circulation. Climatic Change 96, 489-537 (2009).

3. Vellinga, M. \& Wood, R. Impacts of thermohaline circulation shutdown in the twenty-first century. Climatic Change 91, 43-63 (2008).

4. McManus, J., Francois, R., Gherardi, J., Keigwin, L. \& Brown-Leger, S. Collapse and rapid resumption of Atlantic meridional circulation linked to deglacial climate changes. Nature 428, 834-837 (2004).
5. Dickson, B. et al. Rapid freshening of the deep North Atlantic Ocean over the past four decades. Nature 416, 832-837 (2002)

6. Curry, R., Dickson, B. \& Yashayaev, I. A change in the freshwater balance of the Atlantic Ocean over the past four decades. Nature 426, 826-829 (2003).

7. Dickson, R. R., Meincke, J., Malmberg, S.-A. \& Lee, A. J. The "Great Salinity Anomaly" in the Northern North Atlantic 1968-1982. Progress in Oceanography 20, 103-151 (1988).

8. Aagaard, K. \& Carmack, E. C. The role of sea ice and other fresh water in the Arctic circulation. Journal of Geophysical Research: Oceans 94, 14485-14498 (1989).

9. Serreze, M. C. et al. Observational Evidence of Recent Change in the Northern High-Latitude Environment. Climatic Change 46, 159-207 (2000).

10. Sutton, R. T. \& Hodson, D. L. R. Influence of the ocean on North Atlantic climate variability 1871-1999. Journal of Climate 16, 3296-3313 (2003).

11. Drinkwater, K. F. Atmospheric and sea-ice conditions in the northwest Atlantic during the decade, 1991-2000. Journal of Northwestern Atlantic Fisheries Science 34, 1-11 (2004)

12. Marsh, R. et al. The 1882 tilefish kill - a cold event in shelf waters off the northeastern United States? Fisheries Oceanography 8, 39-49 (1999).

13. Lazier, J. R. N. \& Wright, D. G. Annual velocity variations in the Labrador Current. Journal of Physical Oceanography 23, 659-678 (1993).

14. Petrie, B., Loder, J. W., Lazier, J. \& Akenhead, S. Temperature and salinity variability on the eastern Newfoundland shelf: The residual field. AtmosphereOcean 30, 120-139 (1992).

15. Petrie, B. Does the North Atlantic Oscillation affect hydrographic properties on the Canadian Atlantic continental shelf? Atmosphere-Ocean 45, 141-151 (2007)

16. Wanamaker, A. D., Hetzinger, S. \& Halfar, J. Reconstructing mid- to high-latitude marine climate and ocean variability using bivalves, coralline algae, and marine sediment cores from the Northern Hemisphere. Palaeogeography, Palaeoclimatology, Palaeoecology 302, 1-9 (2011).

17. Halfar, J., Steneck, R. S., Joachimski, M., Kronz, A. \& Wanamaker, A. D. Jr. Coralline red algae as high-resolution climate recorders. Geology 36, 463-466 (2008).

18. Adey, W. H. The genus Clathromorphum (Corallinaceae) in the Gulf of Maine. Hydrobiologia 26, 539-573 (1965).

19. Adey, W. H., Lindstrom, S. C., Hommersand, M. H. \& Mueller, K. M. The biogeographic origin of Arctic endemic seaweeds: A thermogeographic view. Journal of Phycology 44, 1384-1394 (2008).

20. Hetzinger, S. et al. High-resolution analysis of trace elements in crustose coralline algae from the North Atlantic and North Pacific by laser ablation ICP-MS Palaeogeography, Palaeoclimatology, Palaeoecology 302, 81-94 (2011).

21. Hetzinger, S. et al. Marine proxy evidence linking decadal North Pacific and Atlantic climate. Climate Dynamics 39, 1447-1455 (2012).

22. Gamboa, G. et al. Mg/Ca ratios in coralline algae record northwest Atlantic temperature variations and North Atlantic Oscillation relationships. Journal of Geophysical Research 115, C12044 (2010)

23. Adey, W. H. \& Steneck, R. Thermogeography over time creates biogeographic regions: A temperature/space/time-integrated model and an abundanceweighted test for benthic marine algae. Journal of Phycology 37, 677-698 (2001)

24. Adey, W. H. Distribution of saxicolous crustose corallines in the Northwestern North Atlantic. Journal of Phycology 2, 49-54 (1966).

25. Halfar, J. et al. Coralline algal growth-increment widths archive North Atlantic climate variability. Palaeogeography, Palaeoclimatology, Palaeoecology 302, 71-80 (2011).

26. Chan, P. et al. Freshening of the Alaska Coastal Current recorded by coralline algal $\mathrm{Ba} / \mathrm{Ca}$ ratios. Journal of Geophysical Research 116, G01032 (2011).

27. Colbourne, E. B., deYoung, B., Narayanan, S. \& Helbig, J. Comparison of hydrography and circulation on the Newfoundland Shelf during 1990-1993 with the long-term mean. Canadian Journal of Fisheries and Aquatic Sciences 54, 68-80 (1997).

28. Colbourne, E. B. \& Fitzpatrick, C. Station 27 oceanographic monitoring station - A long history. Atlantic Zone Montitoring Program Bulletin 3, 18-21 (2003).

29. Colbourne, E. B. Decadal Changes in the Ocean Climate in Newfoundland and Labrador Waters from the 1950 s to the 1990s. Journal of Northwestern Atlantic Fisheries Science 34, 41-59 (2004)

30. Dehairs, F., Chesselet, R. \& Jedwab, J. Discrete suspended particles of barite and the barium cycle in the open ocean. Earth and Planetary Science Letters 49, 528-550 (1980)

31. Bishop, J. K. B. The barite-opal-organic carbon association in oceanic particulate matter. Nature 332, 341-343 (1988).

32. Lea, D. \& Boyle, E. Barium content of benthic foraminifera controlled by bottom water composition. Nature 338, 751-753 (1989).

33. Lea, D., Shen, G. T. \& Boyle, E. A. Coralline barium records temporal variability in equatorial Pacific upwelling. Nature 340, 373-376 (1989).

34. Lea, D. \& Boyle, E. Barium in planktonic foraminifera. Gechemica et Cosmochemica Acta 55, 3321-3331 (1991).

35. Falkner, K. K., MacDonald, R. W., Carmack, E. C. \& Weingartner, T. J. In The Polar Oceans and Their Role in Shaping the Global Environment: The Nansen Centennial Volume, Geophysical Monograph Series eds Johannessen, O. M. Muench, R. D. \& Overland, J. E.) 63-76 (AGU, 1994).

36. Paytan, A., Kastner, M. \& Chavez, F. P. Glacial to Interglacial Fluctuations in Productivity in the Equatorial Pacific as Indicated by Marine Barite. Science 274, 1355-1357 (1996). 
37. Alibert, C. et al. Source of trace element variability in Great Barrier Reef corals affected by the Burdekin flood plumes. Geochim Cosmochim Ac 67, 231-246 (2003).

38. Sinclair, D. J., Kinsley, L. P. J. \& McCulloch, M. T. High resolution analysis of trace elements in corals by laser ablation ICP-MS. Geochim Cosmochim Ac 62, 18891901 (1998).

39. McCulloch, M. T. et al. Coral record of increased sediment flux to the inner Great Barrier Reef since European settlement. Nature 421, 727-730 (2003).

40. Sinclair, D. J. \& McCulloch, M. T. Corals record low mobile barium concentrations in the Burdekin River during the 1974 flood: evidence for limited Ba supply to rivers? Palaeogeography, Palaeoclimatology, Palaeoecology 214, 155-174 (2004).

41. Grove, C. A. et al. Spatial linkages between coral proxies of terrestrial runoff across a large embayment in Madagascar. Biogeosciences 9, 3063-3081 (2012).

42. Myers, R. A., Akenhead, S. A. \& Drinkwater, K. The influence of Hudson Bay runoff and ice-melt on the salinity of the inner Newfoundland Shelf. AtmosphereOcean 28, 241-256 (1990).

43. Petrie, B. \& Drinkwater, K. Temperature and Salinity Variability on the Scotian Shelf and in the Gulf of Maine 1945-1990. Journal of Geophysical Research 98, 20,079-020,089 (1993).

44. Petrie, B. \& Anderson, C. Circulation on the Newfoundland Continental Shelf. Atmosphere Ocean 21, 207-226 (1983).

45. Tang, C. L. A two-dimensional thermodynamic model for sea ice advance and retreat in the Newfoundland marginal ice zone. Journal of Geophysical Research 96, 4723-4737 (1991).

46. Tang, C. L. \& De Tracey, B. M. Space-time variation of mixed-layer properties, heat and salt fluxes, and ice-melt in the Newfoundland marginal ice zone. Journal of Geophysical Research 103, 1177-1191 (1998).

47. Tang, C. L. Oceanographic features in the Newfoundland marginal ice zone, March-April, 1990. Atmosphere-Ocean 30, 151-172 (1992).

48. Cuny, J., Rhines, P. B., Schott, F. \& Lazier, J. Convection above the Labrador Continental Slope. Journal of Physical Oceanography 35, 489-511 (2005).

49. Tang, C. L. \& Ikeda, M. Ice-edge upwelling off the Newfoundland coast during LIMEX. Atmosphere-Ocean 27, 658-681 (1989).

50. Frajka-Williams, E., Rhines, P. B. \& Eriksen, C. C. Physical controls and mesoscale variability in the Labrador Sea spring phytoplankton bloom observed by Seaglider. Deep Sea Research Part I: Oceanographic Research Papers 56, 2144-2161 (2009).

51. Dickson, R. et al. Current estimates of freshwater flux through Arctic and subarctic seas. Progress in Oceanography 73, 210-230 (2007).

52. Hurrell, J. W. Decadal trends in the North Atlantic Oscillation: regional temperatures and precipitation. Science 269, 676-679 (1995).

53. Drinkwater, K. F. Atmospheric and Oceanic Variability in the Northwest Atlantic During the 1980s and Early 1990s. Journal of Northwestern Atlantic Fisheries Science 18, 77-97 (1996).
54. Rignot, E., Koppes, M. \& Velicogna, I. Rapid submarine melting of the calving faces of West Greenland glaciers. Nature Geoscience 3, 187-191 (2010).

55. Bamber, J., van den Broeke, M., Ettema, J., Lenaerts, J. \& Rignot, E. Recent large increases in freshwater fluxes from Greenland into the North Atlantic. Geophysical Research Letters 39, L19501 (2012).

56. Halfar, J. et al. 225 years of Bering Sea climate and ecosystem dynamics revealed by coralline algal growth-increment widths. Geology 39, 579-582 (2011)

57. Adey, W. H., Lindstrom, S. C., Hommersand, M. H. \& Mueller, K. M. The biogeographic origin of Arctic endemic seaweeds: A thermogeographic view. Journal of Phycology 44, 1384-1394 (2008).

58. Paillard, D., Labeyrie, L. \& Yiou, P. Macintosh program performs time-series analysis. Eos Transactions AGU 77, 379 (1996).

59. Hill, B. T. \& Jones, S. J. The Newfoundland Ice Extent and the Solar Cycle From 1860 to 1988. Journal of Geophysical Research 95, 5385-5394 (1990).

\section{Acknowledgements}

We thank B. Williams for discussion and helpful comments. We also thank B. Hooper for support during field work and G. Gamboa and A. Omar for lab assistance. This research was funded by the Alexander von Humboldt Foundation (Feodor Lynen Fellowship to S.H.), a Natural Sciences and Engineering Research Council of Canada Discovery Grant, a Canadian Foundation for Climate and Atmospheric Science Grant, and a Canadian Foundation for Innovation and Research and Ontario Research Fund Grant (all J.H.).

\section{Author contributions}

S.H. and J.H. collected the samples and designed the project. S.H., J.H., T.Z., B.E.K. and D.E.J. analyzed the samples. S.H. and J.V.M. interpreted the data, and S.H. wrote the paper. W.H.A. provided sample material. All authors discussed the results and contributed to the manuscript.

\section{Additional information}

Competing financial interests: The authors declare no competing financial interests.

License: This work is licensed under a Creative Commons Attribution-NonCommercial-NoDerivs 3.0 Unported License. To view a copy of this license, visit http://creativecommons.org/licenses/by-nc-nd/3.0/

How to cite this article: Hetzinger, S. et al. Coralline algal Barium as indicator for 20th century northwestern North Atlantic surface ocean freshwater variability. Sci. Rep. 3, 1761; DOI:10.1038/srep01761 (2013) 